\title{
86. Differentialdiagnostik der Recessus und Ganglien des Kniegelenkes mit Hilfe der Doppelkontrastarthrographie
}

\author{
Th. Stuhler, D. Lattermann, H. Krtsch und K. Stringaris
}

Klinik und Poliklinik für Allgemeinchirurgie der Universität Göttingen (Dir.: Prof. H.-J. Peiper) Radiologische Klinik der Universität Göttingen (Dir.: Prof. H. Poppe)

\section{Differential Diagnose between Recessus and Ganglion of the Knee with the Help of Arthrography}

Summary. The study is based on 50 arthrographic observations of ganglion of the knee treated by surgery, 15 ganglions diagnosed preoperatively by arthrography and 600 arthrographic X-rays for meniscus lesion.

Function-X-ray plates are reproduced to show: (a) the physiologic variation of the posterior capsule; (b) the importance of X-rays taken during flexion and extension in the interpretation of recessus; (c) radiographic characteristics of recessus and ganglion; (d) differential diagnosis between capsule rupture and ganglion. Some discussion follows as to whether recessus could predispose to formation of a ganglion.

Key words: Arthrography - Knee - Recessus - Ganglion.

Zusammenfassung. Der Untersuchung liegen 50 arthrographische Kontrollen operierter Kniekehlenganglien, 15 präoperativ arthrographisch verifizierte Ganglien sowie 600 Doppelkontrastarthrogramme des Kniegelenks zugrunde.

An Hand von Funktionsaufnahmen werden Charakteristica demonstriert: a) physiologische Variante der hinteren Kapsel. b) Bedeutung der Funktionsaufnahme für die Interpretation des Recessus. c) Röntgenologische Kriterien von Recessus und Ganglion. d) Differentialdiagnostik zwischen Kapselriß und Ganglion. Ätiologie: Recessus als mögliche Basis des Ganglions.

Schlïsselwörter: Doppelkontrastarthrographie - Kniegelenk - Recessus - Ganglion.

\section{Knochen-Knorpel-Transplantate bei drohender Durchspießung kindlicher Amputationsstuimpfe}

\author{
G. Neff und E. E. Marquardt
}

Orthopädische Klinik und Poliklinik der Universität Heidelberg, Abteilung für Dysmelie und technische Orthopädie

\section{Bone-Cartilage Grafts to Prevent Overgrowth in Above-Elbow Stumps in Children}

Summary. Repeated reamputation because of overgrowth in above-elbow stumps in children provokes increasing shortening of the stump. 